\title{
The research and practice of college education on technological innovation through college-enterprise cooperation - IT field as an example
}

\author{
Kun Quan Shi ${ }^{1, a}$ and Zhen Lun Yang ${ }^{1, b^{*}}$ \\ ${ }^{1}$ School of Information Engineering, Guangzhou Panyu Polytechnic, Guangzhou 511483, China \\ ashikq@gzpyp.edu.cn, byangzl@gzpyp.edu.cn
}

Keywords: Higher vocational college; College-enterprise cooperation; Technological innovation; Education mode; Research and practice

\begin{abstract}
To meet the trend of technological innovation, cooperation between college and enterprises will be an effective way to foster new talents in technological innovation. By optimizing cooperation and interaction, college-enterprise cooperation can improve the innovative ability among new talents, teachers and the industry with stimulating motivation, improve coordination among different segments, integrating resources in technological innovation process and jointly launching technological innovative activities.
\end{abstract}

\section{Introduction}

The technological innovation theory is proposed and discussed systematically by Schumpeter [1]. According to the theory, the technological innovation is a kind of complicated behavior determined by the innovation subjects and other elements in a complex interaction way. Furthermore, technological innovation is also regarded as the production of technological progress and application. The concept of the college-enterprise cooperation is originally proposed in Europe. In order to provide more human resources with technical skills, the governments of developed countries in Europe and America have carried out the reform of the education system and pushed through some relevant laws and regulations to clarify their respective obligations and responsibilities in the training of human resources with technical skills [2]. The emphasis of the college-enterprise cooperation should lay in theory study in college and business practices in enterprise. Moreover, the sharing of resources and information of college and enterprise improves the practicality and effectiveness of the cooperation.

Innovation is the key to the future of the IT industry. The higher vocational colleges are very important to provide the training to human resources with the application capabilities as well as those with innovation capabilities. Based on the survey to some enterprises, this paper makes some researches and explorations on the college-enterprise cooperation mechanism to IT Education Model in higher vocational colleges. The related work is given in section 1 and the design and implementation of the survey is in section 2. Based on these two sections, the architectural design of win-win model of college-enterprise cooperation for technological innovation is proposed in section 3 . Section 4 demonstrates the practice of the proposed model.

\section{Related work}

There are lots of researches in the innovative human resources training based on the college-enterprise cooperation. Wang [3] proposed the model of training the practice innovative human resource with the tripartite cooperation of college, educational institutions and enterprise. Zhuang et al [4] developed the idea of training the practice innovative human resources based on specific advantages as well as demands of industry and regional economy. Wu and Yang [5] analyzed the factors affecting enterprises to develop college-enterprise cooperation. Some other issues about the construction of innovative practice base and academic competitions platform for students, 
teaching reform, innovative education and internationalization of education research are also discussed in literatures.

From the literatures, we can say that the technological innovation is the demand of the development of society; college-enterprise cooperation is the direction and trend of development of vocational education. The establishment of a good mechanism to stimulate innovation and promote the college-enterprise cooperation is very important.

\section{The survey and analysis (From the perspective of enterprise)}

Good college-enterprise cooperation mechanism is the guarantee for training the innovative human resources. And in-depth survey and analysis can greatly help us to identify the entry point for college-enterprise cooperation, and then to carry out college-enterprise cooperation. We carried out the interviews and questionnaires survey to more than 30 IT companies located in Guangzhou, Zhongshan and Foshan and the statistical analysis is given below.

The most acceptable form of college-enterprise cooperation. For the companies, the most acceptable forms of cooperation are to participate in the design and implementation of training programs $(22 \%)$ as well as order-mode personal training $(13 \%)$. It can also be seen from the figure that for the companies, academic funding $(3 \%)$ is not acceptable .

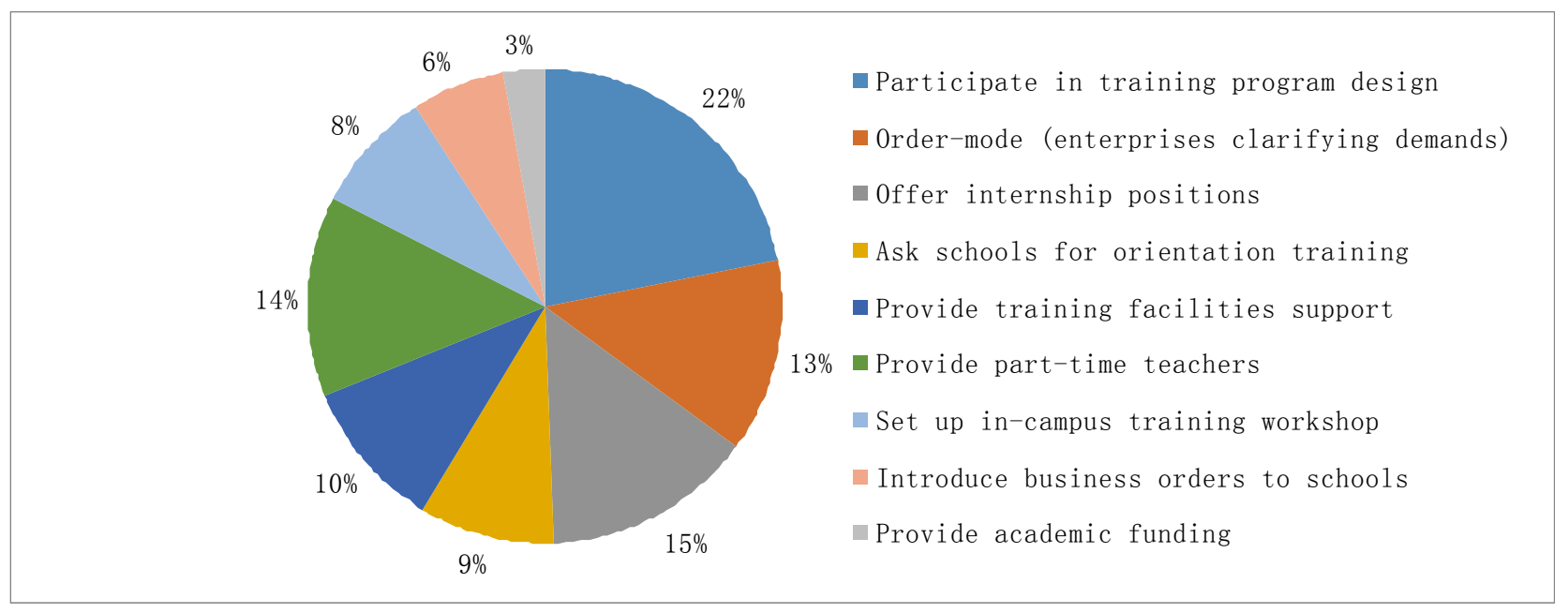

Fig. 1 The most acceptable form of cooperation

The most acceptable activities to improve the innovative ability of vocational students. Survey statistics show that $100 \%$ of companies have expressed their willingness to send technical engineers to participate in the guidance of students in study and contest, while $75 \%$ of companies expressed their willingness to set up the innovation funds to support innovative projects for college students. About $70 \%$ of companies are willing to provide financial and technical support for the students' projects with business prospects.

The establishment of economic entities and IT business alliances. There are $92.9 \%$ of companies willing to use the human resources, consist of teachers and students from vocational colleges, to establish the economic entities. About $93.3 \%$ of the companies are willing to form alliances and share market resources and human resources with colleges. And by occasional interaction, the colleges can understand the business and the market demand while the companies can understand college training model and characteristics of human resources colleges offering.

Table 1 The willingness of companies to the establishment of economic entities and IT business alliances

\begin{tabular}{|c|c|c|}
\hline Items & willingness $(\%)$ & unwillingness (\%) \\
\hline IT business alliances & 93.3 & 6.7 \\
\hline economic entities & 92.9 & 7.1 \\
\hline
\end{tabular}


The preferential policies from the government. About $27 \%$ of companies said they want the government to give tax incentives, $31 \%$ of companies said that they want government to give the subsidies for jobs internship training, $25 \%$ of companies wish bonus for their involvement in vocational education, $16 \%$ companies want the government give them awards to help build up better brand image.

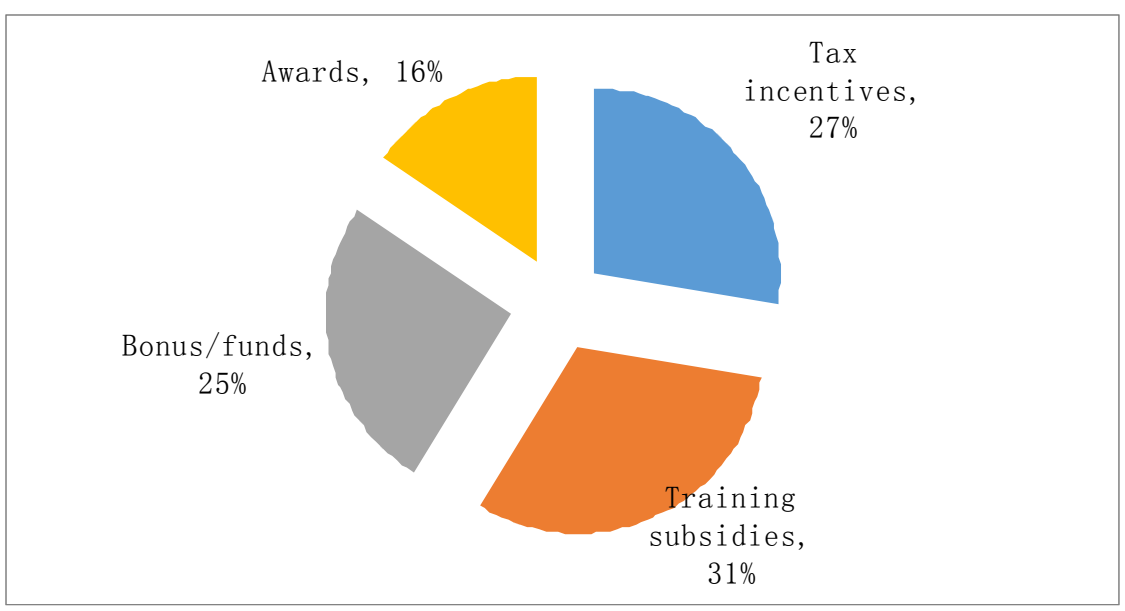

Fig. 2 The preferential policies from the government

\section{A win-win model of technological innovation education}

"one center, a main line, the trinity," the technical innovation education model. In this model, the core is student and the main line is innovative ability and the trinity includes the human resources training, teaching resources construction and services for industries. Colleges, companies, teachers and students have positive interactions with each other and the stimulating mechanism, innovative motivation are optimized in this model. Furthermore, the technical innovative base is established for integrating the resources of college and companies. Thus both the colleges and companies can carry out technical innovation. And their collaborative innovation will provide services for industry and boost industrial upgrading and restructuring.

The lifecycle of innovative human resources training. The innovative education, the innovative ability of teachers, the technical innovation base, the ability of starting a business or being employed, the ability to serve the industrials are the essential elements of the lifecycle of innovative human resources training. Firstly, innovation and creativity were cultivated for students through innovative education. Secondly, as organizers of education, teachers have great impact on the level of innovative human resources training, so the teachers' ability to innovate should be improved. Thirdly, the good atmosphere for scientific and technological culture, various forms of technological innovation platform, technological innovation activities are also important. Fourthly, the target of the model is to train technological innovative human resources, improve student employability and entrepreneurial abilities, enhance the professional services for industries, and enhance the core competitiveness of colleges and companies. 


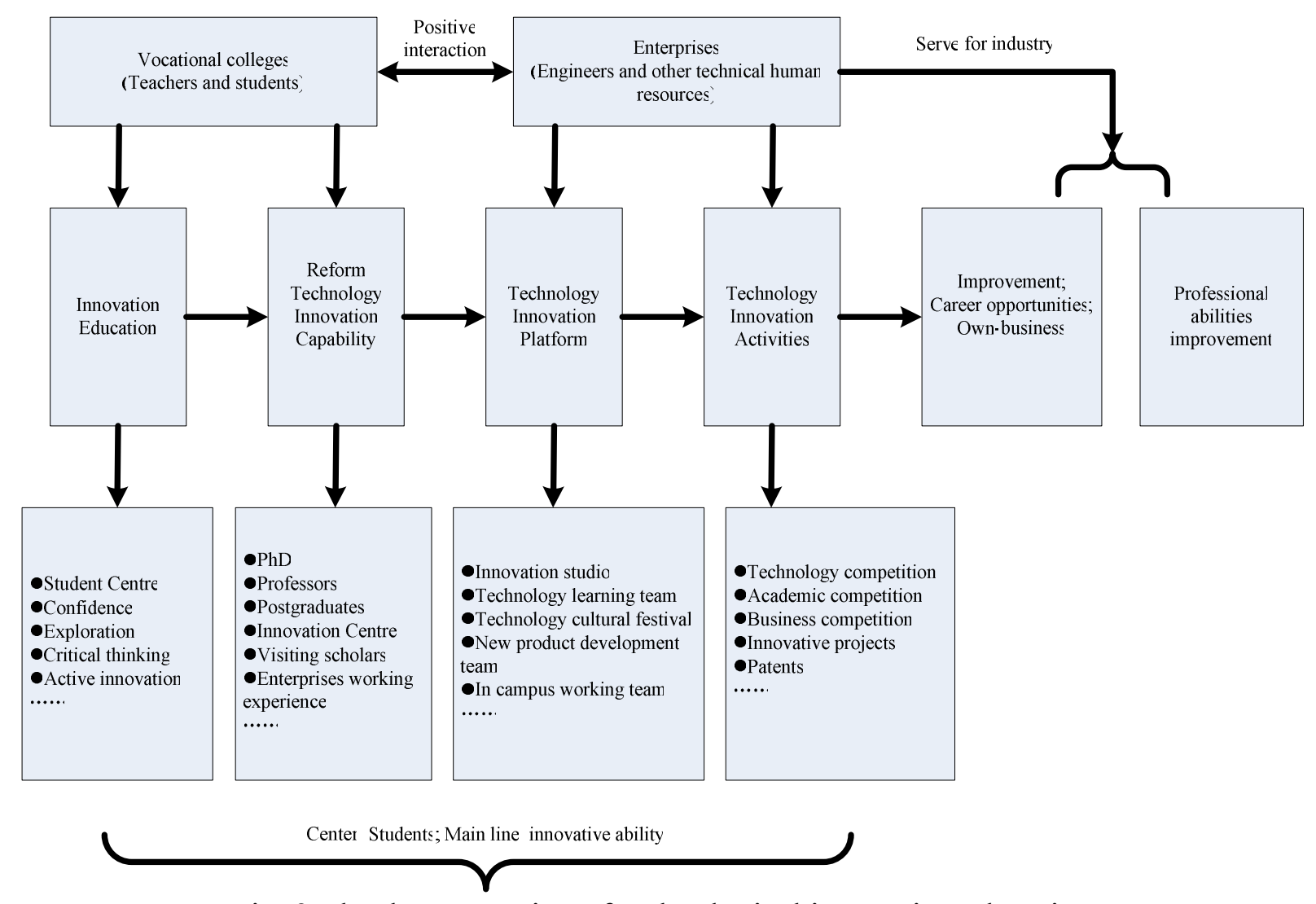

Fig. 3 The demonstration of technological innovative education

\section{The implementation of college-enterprise cooperation for technological innovation}

To develop innovative education. Education is the cornerstone of innovative human resources training. Since the 1990s, American universities adhere to carry out education innovation, adhere to the one center ---- "student is the center", "three combinations" --- a combination of curricular and extra-curricular science and humanities combination of teaching and research combine to form a unique, innovative training model [6]. To develop the innovative sense of student, the teachers should focus on inspiring them to explore, actively innovate and strive for perfection[7]. The awareness and innovation of students can be enhanced by improving their self-confidence. The teacher should respect every single student and use some strategy to stimulate the motivation of students.

To enhance teachers' technological innovation capability. As the guide of students, teachers should have enough technological innovation capability. As an example, our college made a remarkable teacher training program and established the $\mathrm{PhD}$ studio and professor studio. The research institute and development centers were built. Moreover, there are some plans to send young teachers to work in enterprise for at lease one semester. Some teachers were sent to the Hong Kong University of Science and Technology, South China University of Technology and other famous universities as the visiting scholars. For industrial projects, some teachers had the cooperation with companies in developing some new product with the participation of some students.

To create a platform for technological innovation. To improve the innovative ability of students and to enhance the ability of implementation and stimulate the innovative motivation, some useful measures from our previous practice included establishing a technological innovation platform and hosting technological innovation activities had been made. The main approaches were as follows: Firstly, colleges and enterprises worked together to build up the campus cultural phenomenon, such as the annual cultural festival based on computer technology science and technology competitions. Secondly, establishing studios with tutors' guidance could promoted the innovative activities of students and encouraged new product development. Thirdly, the introduction of enterprise project into college brought engineers in the enterprise to students could guide and improve their industrial 
project development practices. Fourthly, technical contests and business plan competitions for students also widened the students' view. On the other hand, the academic competitions and skills competitions also provided a platform for students to implement their skill and thinking.

By creating a platform for technological innovation, technological innovation, employment and entrepreneurial abilities of students were improve notably. For example, a student invented a new concept of electronic locks when he was still in college. After his graduation, he founded his own company and won 100,000RMB special financial funding from the government in the SME Technology Innovation Project.

To server the industries. In recent years, our college focused on providing professional and demand-driven services to industries based on the background of the emerging information industries in Guangzhou and the Pearl River Delta region. The relevant activities include participation in the development of industry standards, research and development of business projects, patents and software copyrights protection, innovative human resources for supporting the development of the industries.

\section{Conclusion}

In this paper, we proposed a win-win model of college-enterprise cooperation for technological innovation. The detail of the model and some implementations were given. However, to train technological innovative human resource in the form of college-enterprise cooperation, there are still several problems to be solved. Firstly, long-term mechanism for college-enterprise cooperation should be built. Secondly, the technological innovation ability of teachers should be improved. Thirdly, the factors affecting the individuals in the cooperation should be considered. Fourthly, policies or laws should boost the enthusiasm of enterprises to participate in vocational education. Fifthly, the technology innovation resource development platform for technological sharing and personnel interaction should be built.

\section{References}

[1] Schumpeter J A. The theory of economic development: An inquiry into profits, capital, credit, interest, and the business cycle [M]. Transaction Publishers, 1934.

[2] Yuan zhisheng. University and company: Win-win strategy management [J]. Technology and management, 2008,10(1):133-134.

[3]Wang weidong. The practice of training the human resources on computer with the college and company cooperation [J]. Computer education, 2010(21): 81-83.

[4]Zhuang zhijun. The practice innovative human resources training with the college and company cooperation [J]. Journal of Jilin Institute of Chemical Technology, 2007(12):10-12.

[5] Wu hongyu, Yang qunxiang. Factor analysis for developing college-enterprise cooperation [J]. Vocational and Technical Education, 2012(33):15-20.

[6]Zhang xiaopeng. Innovative human resouces training mode of American universities [J].University education of China,2001(3):7-11.

[7]Xia hongbin. Competition Education and IT explore innovative training model [J].Journal of software guide, 2009(10): 